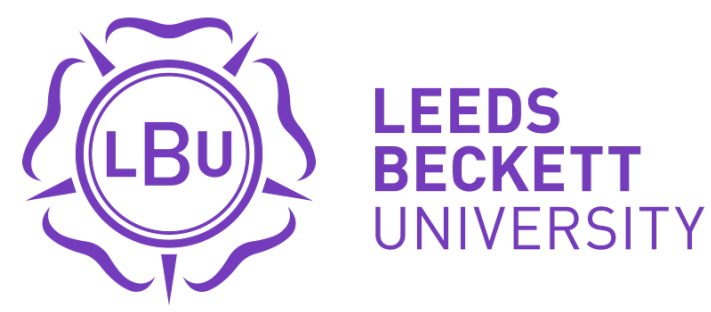

Citation:

Woods, DR and Delves, SK and Britland, SE and Shaw, A and Brown, PE and Bentley, C and Hornby, S and Burnett, A and Lanham-New, SA and Fallowfield, JL (2015) Nutritional status and the gonadotrophic response to a polar expedition. Appl Physiol Nutr Metab, 40 (3). pp. 292-297. ISSN 1715-5320 DOI: https://doi.org/10.1139/apnm-2014-0418

Link to Leeds Beckett Repository record:

https://eprints.leedsbeckett.ac.uk/id/eprint/3066/

Document Version:

Article (Accepted Version)

The aim of the Leeds Beckett Repository is to provide open access to our research, as required by funder policies and permitted by publishers and copyright law.

The Leeds Beckett repository holds a wide range of publications, each of which has been checked for copyright and the relevant embargo period has been applied by the Research Services team.

We operate on a standard take-down policy. If you are the author or publisher of an output and you would like it removed from the repository, please contact us and we will investigate on a case-by-case basis.

Each thesis in the repository has been cleared where necessary by the author for third party copyright. If you would like a thesis to be removed from the repository or believe there is an issue with copyright, please contact us on openaccess@leedsbeckett.ac.uk and we will investigate on a case-by-case basis. 


\section{Nutritional Status and The Gonadotrophic Response to a Polar Expedition}

David R. Woods ${ }^{2,3}$, Simon K. Delves ${ }^{1}$, Sophie E. Britland ${ }^{1}$, Anneliese Shaw ${ }^{1}$, Piete E. Brown $^{1}$, Conor Bentley ${ }^{4}$, Simon Hornby ${ }^{5}$, Anne Burnett ${ }^{6}$, Sue A. Lanham-New ${ }^{7}$, Jo L. Fallowfield $^{1}$

${ }^{1}$ Institute of Naval Medicine, Crescent Road, Alverstoke, PO12 2DL, UK

${ }^{2}$ Royal Victoria Infirmary and Newcastle University, Queen Victoria Road, Newcastle-uponTyne, NE1 4LP, UK

${ }^{3}$ Carnegie Research Institute, Leeds Metropolitan University, LS6 3QS, UK

${ }^{4}$ NIHR SRMRC, Trauma Research, Room 36, 4th Floor, East Block Queen Elizabeth Hospital Research \& Development, University Hospitals Birmingham NHS Foundation Trust Queen Elizabeth Hospital, Queen Elizabeth Medical Centre, Birmingham, B15 2TH, UK

${ }^{5}$ Air Command, High Wycombe, HP14 4UE, UK

${ }^{6}$ Department of Clinical Biochemistry, Royal Victoria Infirmary, Queen Victoria Road, Newcastle-upon-Tyne, NE1 4LP, UK

${ }^{7}$ Nutritional Sciences Department, Faculty of Health and Medical Sciences, University of Surrey, Guildford, GU2 7XH, UK

Correspondence to: D.R. Woods

E-mail: DoctorDRWoods@aol.com

Telephone: 01670564022 


\section{Abstract}

Polar expeditions have been associated with changes in the hypothalamic-pituitarytesticular axis consistent with central hypogonadism (i.e. decreased testosterone, luteinising hormone $[\mathrm{LH}]$ and follicle stimulating hormone $[\mathrm{FSH}])$. These changes are typically associated with body mass loss. Our aim was to evaluate whether maintenance of body mass during a Polar expedition could mitigate against the development of central hypogonadism. Male participants $(\mathrm{n}=22)$ from a 42-day expedition (British Services Antarctic Expedition 2012 [BSAE]) volunteered to take part in the study. Body mass, body composition and strength data were recorded pre- and post-expedition in addition to assessment of serum testosterone, LH, FSH, thyroid hormones, insulin-like growth factor 1 (IGF-1) and trace elements. Energy provision and energy expenditure (EE) were assessed at mid- and endexpedition.

Daily energy provision was $6335 \pm 149 \mathrm{kcal}_{\text {day }}{ }^{-1}$. Estimated EE mid-expedition was $5783 \pm 1690 \mathrm{kcal}^{-d a \mathrm{y}^{-1}}$. Body mass and percentage body fat did not change between preand post-expedition. Total testosterone ( $\mathrm{nmol} / \mathrm{L})(14.0 \pm 4.9$ vs. 17.3 $\pm 4.0, \mathrm{p}=0.006)$, calculated free testosterone (pmol/L) $(288 \pm 82$ vs. $350 \pm 70, \mathrm{p}=0.003)$ and sex hormone binding globulin (SHBG, nmol/L) (33 \pm 12 vs. $36 \pm 11, \mathrm{p}=0.023)$ concentrations increased. $\mathrm{LH}$ and FSH remained unchanged. Thyroid stimulating hormone (TSH, IU/L) (2.1 \pm 0.8 vs. 4.1 $\pm 2.1, \mathrm{p}<0.001)$ and free triiodothyronine (T3, IU/L) $(5.4 \pm 0.4$ vs. 6.1 $\pm 0.8, \mathrm{p}<0.001)$ increased while free thyroxine (T4), IGF-1 and trace elements remained unchanged. Handgrip strength reduced post-expedition but static lift strength was maintained.

Maintenance of body mass and nutritional status appeared to negate the central hypogonadism previously reported from Polar expeditions. The elevated TSH and free T3 were consistent with a previously reported "Polar T3 syndrome".

Key words: Gonadotrophic and thyroid hormones, Nutrition, Energy Balance, Antarctica, 
Cold, BMI .

\section{Introduction}

Acute physiological stress, such as that associated with surgery (Lindh et al. 1992), burns (Lephart et al. 1987), severe illness (Semple et al. 1980) or completing an ultraendurance event (Tauler et al. 2014) are well recognised causes of a rapid reduction in testosterone. Similarly, arduous physical training may also affect the hypothalamicpituitary-testicular axis (Gomez-Merino et al. 2003, Alemany et al. 2008), with testosterone reported to decrease by $50-60 \%$ during United States Ranger and Marine training (Friedl et al. 2000, Alemany et al. 2008). The decrease in testosterone is usually associated with a concomitant decrease in luteinising hormone (LH) and follicle stimulating hormone (FSH), reflecting the development of central hypogonadism (Friedl et al. 2000, Sewani-Rusike et al. 2000). This is most likely due to reduced hypothalamic Gonadotropin-releasing hormone $(\mathrm{GnRH})$ secretion. When measures of energy balance and nutritional status were included in such studies, a significant energy deficit with reductions in body mass, fat free mass and body fat were frequently reported (Guezennec et al. 1994, Sewani-Rusike et al. 2000, Nindl et al. 2007, Alemany et al. 2008).

Similar to endocrine responses to arduous physical training, the physical demands associated with Polar expeditions in the Arctic and Antarctica have also been associated with decreases in testosterone concentrations (Stroud et al. 1997, Gagnon et al. 2011, Johansen et al. 1991). These responses may also be due to central hypogonadism (Stroud et al. 1997). Again, loss of body mass seems a common factor, with a $25 \%$ reduction observed (albeit in only two volunteers) in the data reported by Stroud (Stroud et al. 1997), and a $10 \mathrm{~kg}$ loss reported by Gagnon (Gagnon et al. 2011).

The physical demands of Polar expeditions may parallel the effects of intense physical 
training, and similarly induce central hypogonadism in males secondary to body mass loss. However, very little is known about the pituitary-gonadal response to prolonged physical exercise whilst exposed to extreme cold, especially if body mass is conserved. Our aim was to evaluate whether consumption of the current British Army Cold Climate Ration (which has a greater energy content than conventional rations) during a Polar expedition could prevent significant weight loss. Our hypothesis was that maintaining energy provision at a level to prevent body mass loss on an Antarctic expedition might mitigate the potential for central hypogonadism to occur. 


\section{Materials and Methods}

\section{Ethical Approval}

Ethical approval was obtained from the Ministry of Defence Research Ethics Committee (MODREC 090/GEN/09; Amendment-12). Written informed consent was obtained from all volunteers before data collection commenced and the study was conducted in accordance with the Declaration of Helsinki.

\section{Research Participants}

A cohort of 22 male participants, from the British Services Antarctic Expedition (2012) (BSAE), volunteered to take part in the study. This was a UK Joint Services expedition mounted to the mainland of the Antarctic Peninsula to undertake scientific exploration over 42 days in remote areas. It was organised to commemorate Captain Scott's 1910 1913 expedition. All volunteers were serving members of the UK Armed Forces and had been deemed medically fit to be part of the Expedition team.

\section{Schedule of investigations}

Percentage body fat was assessed in the UK 5 weeks before the expedition began, repeated in the Antarctic immediately prior to and following the expedition and on return to the UK seven days later. Body mass, height and derived body mass index were assessed preexpedition in the UK, immediately following the expedition in the Antarctic and on return to the UK. Blood samples were taken in the UK 5 weeks before the expedition began and immediately on return to the UK seven days after the expedition had finished. Strength measures were also taken in the UK 5 weeks before the expedition and immediately on return to the UK.

Dietary Energy Provision

All participants consumed the UK Ministry of Defence (MOD) Cold Climate Ration (CCR) throughout the expedition. The CCR is comprised of ten daily menu variants 
providing a mean (SD) energy provision of $6335 \pm 149 \mathrm{kcal}$. Of this total energy provision, $50-60 \%$ of the energy is provided as carbohydrates, $7-11 \%$ as protein, and 30-37\% as fat (Vestey Foods UK Ltd., Croydon, UK).

\section{Energy Expenditure}

A Task Analysis Questionnaire (TAQ) was administered at the mid- and end-points of the expedition over two five-day periods. Using daily recall, this method required volunteers to detail and describe their activities each hour over a 24-h period for two blocks of five days. Information from the TAQ was coded, whereby working and nonworking activities were assigned a Metabolic Equivalent (MET) value. Each activity performed throughout a 24-h observation period was assigned a MET value and a 24-h mean MET value calculated. A MET value of between 1.0-1.5 would indicate sedentary activity, 1.6-2.9 would equate to light-intensity, 3.0-5.9 would equate to moderate intensity activity, and $\geq 6.0$ would equate to vigorous intensity. This mean MET value was then multiplied by a participant's body mass $(\mathrm{kg})$, and the duration of the collection period (h), to provide estimated energy expenditure as previously described (Ainsworth et al. 2011).

\section{Anthropometric Assessment}

Anthropometric measures were taken according to the schedule above. Body mass, height and skinfolds were measured. BMI was calculated from the body mass and height measurements. Percent body fat was determined according to the method of Durnin and Womersley with skinfold measurements taken at the biceps, triceps, subscapular and supra-iliac sites (Durnin and Womersley 1974).

\section{Biochemical Assays}

A $7 \mathrm{ml}$ blood sample was drawn from participants seated and rested by medical personnel using serum separation vacutainers according to the schedule above. Serum was allowed to 
clot for a minimum of 30 minutes but no longer than 60 minutes. After centrifugation serum was stored in duplicate plastic 1.5-ml Eppendorf tubes at $-80{ }^{0} \mathrm{C}$. SHBG (nmol/L), LH (IU/L), FSH (IU/L) and TSH (mIU/L) were analysed on the Roche Modular System (Roche Diagnostics, Lewes, UK) by two-site sandwich immunoassay using electro chemiluminesence technology. Testosterone (nmol/L), free T3 (FT3, pmol/L) and free thyroxine (FT4, pmol/L) were also analysed on the Roche Modular System but using competition immunoassay with albumin $(\mathrm{g} / \mathrm{L})$ measured using an endpoint colourimetric method (bromcreosol green). Testosterone and SHBG were used to calculate free testosterone (pmol/L) by the equation: $\{\sqrt{ }[(\mathrm{SHBG}-\mathrm{T}+23) 2+(92 \times \mathrm{T})]-(\mathrm{SHBG}-\mathrm{T}+23)\} / 0.046$ (Vermeulen et al. 1999). The somatotroph axis was assessed by assay of insulin-like growth factor-1 (IGF-1, nmol/L). Assay of IGF-1 was based on chemiluminescence technology using the IDS Isys instrumentation (calibrated to the new WHO international standard).

\section{Trace element assays}

The same serum sample was used to assay magnesium, zinc, copper and selenium pre- and post-expedition in order to reflect micronutrient status.

\section{Strength assessment}

Each test was preceded by a standardised demonstration and an explanation of the test method. Hand-grip strength was measured with volunteers maintaining a standing position, and being requested to exert a maximal, isometric force (measured in $\mathrm{kg}$ ) in the forearms using a hand-grip dynamometer (Takei Model 5401, Cranlea, UK). Following familiarisation, volunteers undertook three repetitions of the test, separated by $30 \mathrm{~s}$ rest, with both hands, where the dominant hand was recorded. Static lift strength was evaluated using an isometric dynamometer (Model 5402, Cranlea, UK). From the dead lift position, volunteers were required to exert a maximal, isometric force in the legs, buttock and back muscles, and the maximum force ( $\mathrm{kg}$ force) generated was recorded. Following a practice 
effort at $50 \%$ of maximum voluntary contraction, volunteers undertook three repetitions of the test separated by $30 \mathrm{~s}$ rest. The best effort was recorded as the volunteer's score.

Statistical Analysis

Data are presented as means, with the standard deviation (SD) being reported in parentheses. Descriptive statistics were determined for the anthropometric and physical work data. Minimum and maximum values and confidence limits $( \pm 95 \%)$ were also determined. Differences between pre- and post-expedition measurements were investigated by Student's paired T-test. Statistical significance was accepted at the $p<0.05$ level. 


\section{Results}

Due to the logistical challenges of such a study not all participants had all data points recorded. Paired data were available for 19-20 subjects. Participants were 36 \pm 7 (range 2348) years old with a height of $1.79 \pm 0.1$ (range 1.65-1.89) m. Body mass, BMI and body fat percentage did not change between pre- and post-expedition in the UK (Table 1). Similarly, there were no differences in body fat percentage between the pre-ice and postexpedition ice measures. Body mass $(82.0 \pm 7.1 \mathrm{~kg}$ to $82.9 \pm 6.8 \mathrm{~kg} ; \mathrm{p}=0.011)$ and $\mathrm{BMI}$ $\left(25.5 \pm 1.7 \mathrm{~kg} \cdot \mathrm{m}^{-2}\right.$ to $\left.25.8 \pm 1.8 \mathrm{~kg} \cdot \mathrm{m}^{-2} ; \mathrm{p}=0.015\right)$ increased by modest amounts between post-expedition ice and post-expedition UK measures.

Mean daily estimated energy expenditure and five-day mean values are presented at Table 2 for the mid-point of the expedition. Significant variability in daily energy expenditure was due to variability in daily activity (an expedition day involving mountaineering was high expenditure compared to a rest day). Estimated daily energy expenditure over 5 days was 5783 (1690) kcal.day ${ }^{-1}$ mid-expedition and 5604 (1534) kcal.day ${ }^{-1}$ at the end of the expedition. The mean energy provision available from rations at this time was 6335 (149) kcal.day ${ }^{-1}$.

The testosterone (total and calculated free), FSH, LH and SHBG of volunteers pre- and post-expedition are presented at Table 3. Both total testosterone $(\mathrm{p}=0.006)$ and calculated free testosterone $(\mathrm{p}=0.003)$ increased between the pre- and post-expedition measurement points. There was also a slight rise in SHBG $(\mathrm{p}=0.023)$ but LH and FSH remained unchanged. $\mathrm{TSH}$, free $\mathrm{T} 3$, free $\mathrm{T} 4, \mathrm{IGF}-1$, albumin and protein data are shown at Table 4. There were increases in serum concentrations of TSH $(\mathrm{p}<0.0001)$ and free T3 $(p<0.001)$ with free T4 remaining unchanged. Serum concentrations of total protein $(\mathrm{p}=0.014)$ and albumin $(\mathrm{p}=0.015)$ decreased between pre- and post-expedition.

The trace elements magnesium, zinc, copper and selenium showed no change pre- and post- 
expedition and remained within the normal reference range. Data are presented at Table 5. Strength assessment revealed a decrease $(\mathrm{P}<0.01)$ in both dominant and non-dominant handgrip strength post-expedition but static lift strength, and static lift strength relative to body mass, were maintained. Data are presented in Table 6. 


\section{Discussion}

Polar expeditions still represent significant physical and physiological challenges to humans, being associated with extreme climate, rapid and unpredictable changes in local weather, as well as the arduous, rugged and geographically remote terrain. Moving through this environment requires intense physical effort, which is associated with high rates of daily energy expenditure. Consumption of the CCR facilitated maintenance of body mass and micronutrient status. Most studies investigating the physical responses to Polar expeditions have reported a decrease in body mass, with a concomitant reduction in circulating testosterone concentrations (Stroud et al. 1997, Gagnon et al. 2011, Johansen et al. 1991) in a pattern consistent with central hypogonadism (Stroud et al. 1997).

In contrast, serum calculated free testosterone concentrations increased between pre and post-expedition in the present study. As total testosterone and SHBG concentrations also increased, the increase in free testosterone was due to a primary increase in testosterone, not a decrease in specific binding proteins.

Estimated energy expenditure mid-expedition was 5783 (1690) kcal.day ${ }^{-1}$, whereas the

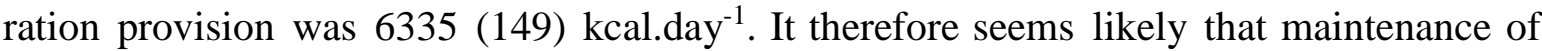
energy status, as evidenced by conservation of body mass and percentage body fat, prevented a decrease in testosterone. Although albumin and protein concentrations decreased slightly, values remained well within the normal range. Unchanged IGF-1 concentrations further support maintenance of energy status. It is known that IGF-1 decreases dramatically when volunteers are in an energy deficient state (Friedl et al. 1985, Livingstone 2013), such that IGF-1 has been proposed as a biomarker of nutritional status (Livingstone 2013).

While conservation of body mass and body fat seem clearly able to prevent the onset of hypogonadism during Polar expeditions, the mechanism that led to an actual rise in 
testosterone concentrations are less clear. It is known that there may be some circannual variation in testosterone during a year of exposure to Antarctica seasons (Sawhney et al.1998). The Antarctic seasons are the opposite of those of the Northern hemisphere, with peak summer from January to February, "autumn" in March, and winter from April to September. Sawhney et al. (1998) reported increased testosterone concentrations during the early months of the visit in nine male volunteers during a 12month stay in Antarctica. Testosterone concentrations peaked in April, with the lowest concentrations being recorded between July-August (i.e. the Antarctica winter). In Europe, seasonal variation in testosterone concentrations has also been reported, with peak concentrations in July. However, peak LH concentrations occur in January, which would suggest that seasonal variation in testosterone is independent of pituitary regulation, and could be due to an independent testicular mechanism (Bellastella 1983). Wehr et al. (2010) reported a similar pattern, with nadir testosterone concentrations in a large European cohort in March, and peak values in August. More recent work supports an independent testicular mechanism (Bellastella et al. 2013), and it has been postulated that increased light levels would exert a positive effect on gonadal function, possibly through inhibition of melatonin secretion (Bellastella et al. 2014).

It therefore seems reasonable to postulate that the maintenance of energy status during the expedition in the present study prevented the onset of central hypogonadism. Having left the low light intensity of a British winter (early January), the increased light levels of Antarctica could have facilitated a rise in testosterone concentration due to a testicular mechanism. The expedition took place during the peak of the Antarctica summer with virtually 24-hour daylight, when such an effect would be expected to be maximal.

Maintenance of testosterone concentrations in a polar environment may be beneficial in the acclimatisation to the cold. In vitro, testosterone has been shown to reduce lipolytic 
activity in cultured brown adipose tissue (Monjo et al. 2003). Thus, if energy status was maintained in cold weather, an increase in testosterone could be a means of conserving fat mass to aid maintenance of body heat. Furthermore, an increase in testosterone would also be of benefit to erythropoiesis and protein synthesis, which may be advantageous when exercising or undertaking physical work in cold weather (Gonzales et al. 2009). Despite this rise in testosterone however hand-grip strength did reduce over the course of the expedition, though static lift strength was maintained.

In the present study, TSH and free $\mathrm{T} 3$ increased between pre- and post-expedition measurements, whilst free T4 remained unchanged. This pattern of increased thyroid activity was consistent with the "Polar T3 Syndrome" reported previously following longer Antarctica exposure (Do et al. 1996). Free T3 is an important regulator of metabolic rate and thermal control, such that an increase in T3 with cold exposure would be a physiologically consistent response. The Polar T3 Syndrome has previously been reported after several months of residence in Antarctica. As such, the changes observed in the present study after 42-days exposure represents a novel finding.

One of the limitations of our study was that baseline body mass and blood samples, due to logistical constraints, had to be taken five weeks prior to the expedition starting. While post-expedition blood samples were taken immediately on arrival back to the UK (at the airport) this was seven days after the expedition had finished. We cannot exclude these factors as being a bias in our results.

\section{Conclusion}

Energy status and body mass were maintained during the BSAE Polar expedition, and thus appeared to prevent the previously observed central hypogonadism. This finding has important implications, not only for expeditionary and military medicine, but also for 
patients who may become malnourished through associated illness. In addition, it could be postulated that the rise in testosterone documented in the present study may be facilitated by increased sunlight exposure, possibly mediated by suppression of melatonin secretion. Finally, this study has provided further evidence of a "Polar T3 syndrome" that may be a beneficial adaptation to the cold. 


\section{Acknowledgements}

All members of the BSAE 2012. Vestey Foods, UK Ltd.

(C) British Crown Copyright 2014/MOD. Published with the permission of the Controller of Her Britannic Majesty’s Stationery Office.

None of the authors had any conflicts of interest. 


\section{References}

Ainsworth BE, Haskell WL, Herrmann SD, Meckes N, Bassett DR, Tudor-Locke C,

Greer JL, Vazina J, Whitt-Glover MC and Leon AS. 2011 Compendium of Physical Activities: A Second Update of Code and MET values. Med Sci Sports Ex 43 (8):1575-1581.

Alemany JA, Nindl BC, Kellogg MD, Tharion WJ, Young AJ and Montain SJ. 2008. Effects of dietary protein content on IGF-I, testosterone, and body composition during 8 days of severe energy deficit and arduous physical activity. J Appl Physiol 105 (1):58-64.

Bellastella A, Criscuolo T, Mango A, Perrone L, Sinisi AA and Faggiano M. 1983. Circannual rhythms of plasma luteinizing hormone, follicle-stimulating hormone, testosterone, prolactin and cortisol in prepuberty. Clin Endocrinol (Oxf)19 (4):453-9.

Bellastella A, De Bellis A, Bellastella G and Esposito K. 2014. Opposite Influence of Light and Blindness on Pituitary-Gonadal Function. Front Endocrinol (Lausanne) 4: 205 .

Bellastella G, Pane E, Iorio S, De Bellis A and Sinisi AA. 2013. Seasonal variations of plasma gonadotropin, prolactin, and testosterone levels in primary and secondary hypogonadism: evidence for an independent testicular role. J Endocrinol Invest 36 (5):339-42.

Do NV, LeMar H and Reed HL. 1996. Thyroid hormone responses to environmental cold exposure and seasonal change: a proposed model. Endocrinology and Metabolism 3: 7-16.

Durnin JV and Womersley J. 1974. Body fat assessed from total body density and its estimation from skinfold thickness: measurements on 481 men and women aged from 16 to 72 years. Brit J of Nutr 32 (1): 77-97. 
Friedl KE, Moore RJ, Hoyt RW, Marchitelli LJ, Martinez-Lopez LE and Askew EW. 2000. Endocrine markers of semistarvation in healthy lean men in a multistressor environment. J Appl Physiol 88 (5):1820-1830.

Gagnon DD, Pullinen T, Karinen H, Rintamäki H and Kyröläinen H. 2011. Recovery of hormonal, blood lipid, and hematological profiles from a North Pole expedition. Aviat Space Environ Med 82 (12):1110-7.

Gomez-Merino D, Chennaoui M, Burnat P, Drogou C and Guezennec CY. 2003. Immune and hormonal changes following intense military training. Mil Med $\mathbf{1 6 8}$ (12):1034-8.

Gonzales GF, Gasco M, Tapia V and Gonzales-Castaneda C. 2009. High serum testosterone levels are associated with excessive erythrocytosis of chronic mountain sickness in men. American Journal of Physiology 296 (6): E1319-E1325.

Guezennec CY, Satabin P, Legrand H and Bigard AX. 1994 Physical performance and metabolic changes induced by combined prolonged exercise and different energy intakes in humans. Eur J Appl Physiol 68 (6): 525-530.

Johansen AT and Norman N. 1991. Reproductive hormones during 42 days of maximal physical effort, low temperatures and general hardship. Arctic Med Res 50 (suppl 6):142-7.

Lephart ED, Baxter CR and Parker CR Jr. 1987. Effect of burn trauma on adrenal and testicular steroid hormone production. J Clin Endocrinol Metab 64 (4):842-848.

Lindh A, Carlström K, Eklund J and Wilking N. 1992. Serum steroids and prolactin during and after major surgical trauma. Acta Anaesthesiol Scand 36 (2):119-24.

Livingstone C. 2013. Insulin-like growth factor-I (IGF-I) and clinical nutrition. Clin Sci (Lond) 125 (6):265-80. 
Monjo M, Rodriguez AM, Palou A and Roca P. 2003. Direct effects of testosterone,

17 beta-estradiol, and progesterone on adrenergic regulation in cultured brown adipocytes: potential mechanism for gender-dependent thermogenesis.

Endocrinology 144 (11): 4923-4930.

Ni ndl BC, B arnes BR, Aleman y JA, Frykman PN, Shippee RL and Friedl KE. 2007. Physiological consequences of U.S. A rmy Ranger training. Med Sci Sports Exer c 39 (8):1380-7.

Saw hney RC, Malhotra AS, P rasa d R, Pal K, Kumar R and Bajaj AC. 1998. Pitu itarygonad al ho rmones during prolonged residency in Antarctica. Int J Biometeorol 42 (1): 51-54.

Semple PD, Beastall GH, Watson WS and Hume R. 1980. Serum testosterone depression associated with hypoxia in respiratory failure. Clin Sci (Lond) $\mathbf{5 8}$ (1):105-6.

Sewani-Rusike CR, Mudambo KS, Tendaupenyu G, Dzuda C, Tafirenyika A and Zenda E. 2000. Effects of the Zimbabwe Defence Forces training programme on body composition and reproductive hormones in male army recruits. Cent Afr J Med 46 (2):27-31.

Stroud MA, Ritz P, Coward WA, Sawyer M, Constantin-Teodosiu D, Greenhaff PL and Macdonald IA. 1997. Energy expenditure using isotope-labelled water $(2 \mathrm{H} 2(18) \mathrm{O})$ exercise performance, skeletal muscle enzyme activities and plasma biochemical parameters in man during 95 days endurance exercise with inadequate energy intake. Eur J of Appl Physiol 76 (3):243 - 252.

Tauler P, Martinez S, Moreno C, Pau Martínez P, Aguilo A. 2014. Changes in salivary hormones, immunoglobulin A, and C-reactive protein in response to ultra-endurance exercises. Applied Physiology, Nutrition, and Metabolism 39 (5): 560-565. 
Vermeulen A, Verdonck L and Kaufman JM. 1999. A critical evaluation of simple methods for the estimation of free testosterone in serum. J Clin Endocrinol Metab 84 (10): $3666-3672$

Wehr E, Pilz S, Boehm BO, März W and Obermayer-Pietsch B. 2010. Association of vitamin D status with serum androgen levels in men. Clin Endocrinol (Oxf) 73 (2):243-248. 


\section{Tables and Figures}

Table 1: Age and Physical Characteristics of BSAE 2012 volunteers pre- and postexpedition - in the UK and on the Ice Measures; Mean (SD), Minimum and Maximum Values and $95 \%$ Confidence Intervals (CI).

Table 2: Mean (SD) Metabolic Equivalent (MET) and estimated energy expenditure (EE) from MET of male volunteers over a 5-day observation period at the mid-point of the expedition.

Table 3: Mean (SD) Gonadotrophic Hormones pre- and post-expedition.

Table 4: Mean (SD) Thyroid Hormones (Thyroid Stimulating Hormone, TSH: Free Triiodothyronine, T3; and, T4), IGF-1, Total Protein and Albumin pre- and postexpedition.

Table 5: Mean (SD) trace element (Magnesium, Zinc, Copper and Selenium) concentrations $(\mathrm{n}=20)$ pre- and post-expedition.

Table 6: Mean (SD) hand grip strength (dominant and non-dominant), static lift strength and static lift strength relative to body mass $(n=20)$ pre- and post-expedition. 
Table 1: Physical Characteristics of participants pre- and post-expedition - in the UK and on the Ice Measures; Mean (SD), Minimum and Maximum Values and 95\% Confidence Intervals (CI).

\begin{tabular}{|c|c|c|c|}
\hline & Body Mass (kg) & BMI $\left(\right.$ kg.m $\left.^{-2}\right)$ & Body Fat (\%) \\
\hline $\begin{array}{l}\text { Pre-Expedition } \\
\text { UK }(n=20)\end{array}$ & $82.9(7.8)$ & $25.8(1.7)$ & $19.8(3.5)$ \\
\hline Minimum & 70.0 & 23.3 & 14.0 \\
\hline Maximum & 100.7 & 29.4 & 25.4 \\
\hline $95 \% \mathrm{CI}$ & 3.4 & 0.7 & 1.5 \\
\hline $\begin{array}{l}\text { Pre-Expedition } \\
\text { Ice }(n=19)\end{array}$ & - & - & $20.4(3.3)$ \\
\hline Minimum & - & - & 13.9 \\
\hline Maximum & - & - & 25.7 \\
\hline $95 \% \mathrm{CI}$ & - & - & 1.5 \\
\hline $\begin{array}{l}\text { Post-Expedition } \\
\text { Ice }(\mathbf{n = 2 0 )}\end{array}$ & $82.0(7.1)$ & $25.5(1.7)$ & $19.2(3.4)$ \\
\hline Minimum & 67.4 & 22.7 & 12.1 \\
\hline Maximum & 94.6 & 29.4 & 26.0 \\
\hline $95 \% \mathrm{CI}$ & 3.1 & 0.7 & 1.5 \\
\hline $\begin{array}{l}\Delta \text { Pre-Ice vs. Post- } \\
\text { Ice }\end{array}$ & 0.0 & 0.0 & 1.2 \\
\hline $\begin{array}{l}\Delta \text { Pre-UK vs. Post- } \\
\text { Ice }\end{array}$ & -0.9 & -0.3 & -0.6 \\
\hline $\begin{array}{l}\text { Post Expedition } \\
\text { UK }(n=20)\end{array}$ & $82.9(6.8)$ & $25.8(1.8)$ & $19.8(3.3)$ \\
\hline Minimum & 68.9 & 22.8 & 13.3 \\
\hline Maximum & 95.6 & 30.3 & 26.1 \\
\hline $95 \% \mathrm{CI}$ & 3.0 & 0.8 & 1.5 \\
\hline $\begin{array}{l}\Delta \text { Post-Ice vs. Post- } \\
\text { UK }\end{array}$ & $+0.9 *$ & $+0.3^{*}$ & +0.6 \\
\hline$\Delta$ Pre-UK vs. Post- & 0.0 & 0.0 & 0.0 \\
\hline
\end{tabular}

Note: $* \mathrm{P}<0.05$ 
Table 2: Mean (SD) Metabolic Equivalent (MET) and estimated energy expenditure (EE) from MET of male volunteers over a 5-day observation period at the mid-point of the expedition.

\begin{tabular}{lcccccc}
\hline & $\begin{array}{c}\text { Day-1 } \\
(\mathbf{n = 2 0})\end{array}$ & $\begin{array}{c}\text { Day-2 } \\
(\mathbf{n = 1 9})\end{array}$ & $\begin{array}{c}\text { Day-3 } \\
(\mathbf{n = 2 0})\end{array}$ & $\begin{array}{c}\text { Day-4 } \\
(\mathbf{n = 2 0})\end{array}$ & $\begin{array}{c}\text { Day-5 } \\
(\mathbf{n = 2 0})\end{array}$ & $\begin{array}{c}\text { 5-Day Mean } \\
(\mathbf{n = 2 0})\end{array}$ \\
\hline MET & $3.6(1.4)$ & $1.8(1.0)$ & $3.7(1.6)$ & $2.0(1.4)$ & $3.5(1.8)$ & $2.9(0.7)$ \\
Min & 1.0 & 1.0 & 1.0 & 1.0 & 1.0 & 1.5 \\
Max & 6.7 & 4.4 & 6.7 & 5.2 & 6.0 & 4.7 \\
\hline EE & 7188 & 3530 & 7244 & 3959 & 6694 & 5783 \\
$($ kcal.day-1) & $(3058)$ & $(2129)$ & $(3227)$ & $(2842)$ & $(3284)$ & $(1690)$ \\
Min & 1941 & 1880 & 1988 & 1701 & 1848 & 2812 \\
& & & & & & \\
Max & 13727 & 8545 & 13209 & 10402 & 11132 & 9999 \\
\hline
\end{tabular}


Table 3: Mean (SD) Gonadotrophic Hormones of Male Volunteers $(n=20)$ pre- and postexpedition.

\begin{tabular}{lccccc}
\hline & $\begin{array}{c}\text { Testosterone } \\
(\mathbf{n m o l} / \mathbf{L})\end{array}$ & $\begin{array}{c}\text { Calculated Free } \\
\text { Testosterone } \\
(\mathbf{p m o l} / \mathbf{L})\end{array}$ & $\begin{array}{c}\text { SHBG } \\
(\mathbf{n m o l} / \mathbf{L})\end{array}$ & LH (IU/L) & FSH (IU/L) \\
\hline $\begin{array}{l}\text { Pre- } \\
\text { Expedition }\end{array}$ & & & & & \\
Mean (SD) & $14.0(4.9)$ & $288(82)$ & $33(12)$ & $4.4(1.4)$ & $4.8(3.4)$ \\
Min & 7.4 & 113 & 12 & 2.0 & 2.0 \\
Max & 27.2 & 394 & 66 & 8.0 & 16.6 \\
\hline Post- & & & & & \\
Expedition & $17.3(4.0)^{* 1}$ & $350(70) * 2$ & $36(11)^{* 3}$ & $4.4(1.5)$ & $4.9(4.0)$ \\
Mean (SD) & 13.1 & 258 & 20 & 1.9 & 2.1 \\
Min & 30.1 & 527 & 68 & 7.6 & 18.9 \\
Max & $6.7-25.7$ & $215-760$ & $15-48$ & $1.8-8.2$ & $1.4-14.0$ \\
\hline Normal Range & & & & & \\
\hline
\end{tabular}

Note:

${ }^{* 1}$ Difference Pre- vs. Post- (P=0.006) (Paired T-test)

${ }^{2}$ Difference Pre- vs. Post- $(\mathrm{P}=0.003)$ (Paired T-test)

${ }^{*}{ }^{3}$ Difference Pre- vs. Post- $(\mathrm{P}=0.023)$ (Paired T-test) 
Table 4: Mean (SD) Thyroid Hormones (Thyroid Stimulating Hormone, TSH: Free Triiodothyronine, T3; and, T4), IGF-1, Total Protein and Albumin pre- and postexpedition.

\begin{tabular}{lcccccc}
\hline & $\begin{array}{c}\text { TSH } \\
(\mathbf{m I U} / \mathbf{L})\end{array}$ & $\begin{array}{c}\text { T3 } \\
(\mathbf{p m o l} / \mathbf{L})\end{array}$ & $\begin{array}{c}\text { T4 } \\
(\mathbf{p m o l} / \mathbf{L})\end{array}$ & $\begin{array}{c}\text { IGF-1 } \\
(\mathbf{n m o l} / \mathbf{L})\end{array}$ & $\begin{array}{c}\text { Total } \\
\text { Protein } \\
(\mathbf{g} / \mathbf{L})\end{array}$ & $\begin{array}{c}\text { Albumin } \\
(\mathbf{g} / \mathbf{L})\end{array}$ \\
\hline $\begin{array}{l}\text { Pre- } \\
\text { Expedition }\end{array}$ & $\begin{array}{c}2.1 \\
(0.8)\end{array}$ & $\begin{array}{c}(0.4) \\
\text { Min }\end{array}$ & $\begin{array}{c}16.7 \\
(1.3)\end{array}$ & $\begin{array}{c}24.1 \\
(5.6)\end{array}$ & $\begin{array}{c}77 \\
(3)\end{array}$ & $\begin{array}{c}51 \\
(2)\end{array}$ \\
Max & 4.1 & 4.6 & 13.5 & 15.0 & 73 & 46 \\
\hline Post- & $4.1(2.1)^{* 1}$ & $6.1(0.8)^{* 2}$ & $16.4(1.8)$ & $26.2(5.8)$ & $75(4)^{* 3}$ & $50(2)^{* 4}$ \\
Expedition & 1.9 & 5.0 & 14.1 & 16.0 & 64 & 46 \\
Min & 10.9 & 7.8 & 20.5 & 41.0 & 81 & 55 \\
Max & $0.3-4.7$ & $3.5-6.5$ & $9.5-21.5$ & $\#$ & $60-80$ & $35-50$ \\
\hline $\begin{array}{l}\text { Normal } \\
\text { Range }\end{array}$ & & & & & & \\
\hline
\end{tabular}

Notes:

\# Reference values for IGF-1 differ depending on age: $17-18$ y, $20-56 \mathrm{nmol} / \mathrm{L} ; 19-20 \mathrm{y}$, $21-85 \mathrm{nmol} / \mathrm{L} ; 21-25 \mathrm{y}, 18-42 \mathrm{nmol} / \mathrm{L}$; and $26-39 \mathrm{y}, 15-37 \mathrm{nmol} / \mathrm{L}$.

${ }^{* 1}$ Difference Pre- vs. Post- $(\mathrm{P}=0.000)$ (Paired T-test)

$*^{2}$ Difference Pre- vs. Post- $(\mathrm{P}=0.000)$ (Paired T-test)

${ }^{3}$ Difference Pre- vs. Post- $(\mathrm{P}=0.014)$ (Paired T-test)

${ }^{*}{ }^{4}$ Difference Pre- vs. Post- $(\mathrm{P}=0.015)$ (Paired T-test) 
Table 5: Mean (SD) trace element (Magnesium, Zinc, Copper and Selenium) concentrations $(\mathrm{n}=20)$ pre- and post-expedition.

\begin{tabular}{lcccc}
\hline & $\begin{array}{c}\text { Magnesium } \\
(\boldsymbol{\mu} \text { mol.L. }\end{array}$ & $\begin{array}{c}\text { Zinc } \\
\left(\boldsymbol{\mu} \text { mol.L } \mathbf{L}^{-1}\right)\end{array}$ & $\begin{array}{c}\text { Copper } \\
\left(\boldsymbol{\mu m o l . L ^ { - 1 } )}\right.\end{array}$ & $\begin{array}{c}\text { Selenium } \\
\left(\boldsymbol{\mu m o l . L ^ { - 1 } )}\right.\end{array}$ \\
\hline Pre-Expedition & & & & \\
Mean (SD) & $0.78(0.07)$ & $12.55(1.23)$ & $14.63(2.05)$ & $1.18(0.13)$ \\
Min & 0.63 & 10.90 & 11.80 & 0.95 \\
Max & 0.90 & 14.9 & 19.1 & 1.44 \\
\hline Post-Expedition & & & & \\
Mean (SD) & $0.80(0.05)$ & $12.61(1.38)$ & $14.05(1.76)$ & $1.18(0.13)$ \\
Min & 0.71 & 9.12 & 10.60 & 0.86 \\
Max & 0.89 & 14.9 & 18.5 & 1.35 \\
\hline Normal Range & $0.65-1.00$ & $11-24$ & $11-120$ & $0.89-1.65$ \\
\hline
\end{tabular}


Table 6: Mean (SD) hand grip strength (dominant and non-dominant), static lift strength and static lift strength relative to body mass $(n=20)$ pre- and post-expedition.

\begin{tabular}{lcccc}
\hline & \multicolumn{2}{c}{ Hand-Grip Strength } & \multicolumn{2}{c}{ Static Lift Test } \\
& $\begin{array}{c}\text { Dominant } \\
(\mathbf{k g})\end{array}$ & $\begin{array}{c}\text { Non-Dominant } \\
(\mathbf{k g})\end{array}$ & $\begin{array}{c}\text { Static Lift } \\
(\mathbf{k g})\end{array}$ & $\begin{array}{c}\text { Static Lift / } \\
\text { Body Mass }\end{array}$ \\
\hline Pre-Expedition & & & & \\
Mean (SD) & $55.8(6.7)$ & $54.6(7.0)$ & $131.2(25.1)$ & $1.6(0.3)$ \\
Min & 42.6 & 43.2 & 67.0 & 0.8 \\
Max & 73.2 & 72.8 & 168.5 & 2.2 \\
\hline Post-Expedition & & & & \\
Mean (SD) & $52.6(4.8)^{* *}$ & $50.7(5.8)^{* *}$ & $129.9(21.4)$ & $1.5(0.5)$ \\
Min & 44.9 & 41.3 & 78.0 & 0.0 \\
Max & 60.2 & 60.9 & 173.5 & 2.2 \\
\hline
\end{tabular}

Note: $* * \mathrm{P}<0.01$ 